\title{
A scoping review of Lyme disease research relevant to public health
}

\author{
JD Greig ${ }^{1 *}$, I Young ${ }^{2}$, S Harding ${ }^{1}$, M Mascarenhas ${ }^{1}$, LA Waddell ${ }^{1}$
}

\begin{abstract}
Lyme disease (LD) is an emerging infectious disease in Canada associated with expansion of the geographic range of the tick vector Ixodes scapularis in eastern and central Canada. A scoping review of published research was prioritized to identify and characterize the scientific evidence concerning key aspects of LD to support public health efforts. Prior to initiation of this review, an expert advisory group was surveyed to solicit insight on priority topics and scope. A pre-tested search strategy implemented in eight databases (updated September 2016) captured relevant research. Pre-tested screening and data characterization forms were completed by two independent reviewers and descriptive analysis was conducted to identify topic areas with solid evidence and knowledge gaps. Of 19,353 records screened, 2,258 relevant articles were included in the review under the following six public health focus areas: a) surveillance/monitoring in North America $(n=809) ;$ b) evaluation of diagnostic tests $(n=736)$; c) risk factors $(n=545)$; d) public health interventions ( $n=205)$; e) public knowledge, attitudes and/or perceptions in North America ( $n=202)$; and $f$ ) the economic burden of LD or cost-benefit of interventions $(n=32)$. The majority of research investigated Borrelia burgdorferi $(n=1,664)$, humans $(n=1,154)$ and Ixodes scapularis $(n=459)$. Sufficient research was identified for potential systematic reviews in four topic areas: a) accuracy of diagnostic tests; b) risk factors for human illness; c) efficacy of LD intervention strategies; and d) prevalence and/or incidence of LD in humans or B. burgdorferi sensu stricto in vertebrate reservoirs or ticks in North America. Future primary research could focus on closing knowledge gaps, such as the role of less studied vertebrate reservoirs in the transmission cycle. Results of this scoping review can be used to quickly identify and summarize relevant research pertaining to specific questions about LD or B. burgdorferi sensu lato in humans, vertebrate hosts or vectors, providing evidence-informed information within timelines that are conducive for public health decision-making.
\end{abstract}

\author{
Affiliations \\ ${ }^{1}$ National Microbiology \\ Laboratory at Guelph, Public \\ Health Agency of Canada, \\ Guelph, ON \\ 2 School of Occupational and \\ Public Health, Ryerson University, \\ Toronto, ON
}

*Correspondence: judy.greig@ canada.ca

Suggested citation: Greig JD, Young I, Harding S, Mascarenhas M, Waddell LA. A scoping review of Lyme disease research relevant to public health. Can Commun Dis Rep 2018;44(10):243-56. https://doi.org/10.14745/ ccdr.v44i10a03

Keywords: Scoping review, Lyme disease, public health, Ixodes ticks, research

\section{Introduction}

Lyme disease (LD) is the most common tick-borne infection affecting humans in North America and Eurasia (1). It is a multisystem infectious disease caused by bacteria of the Borrelia burgdorferi sensu lato (s.l.) species complex comprising more than 20 genospecies, including the human pathogens B.burgdorferi sensu stricto (s.s) in North America and B. garinii, B. afzelii, B. burgdorferi s.s., B. spielmanii, B. bissettii and B. bavariensis in Europe (2,3). In Canada, LD is an emerging issue, and human cases have increased six-fold (from 144 to 917 cases) between 2009 and 2015 as Ixodes scapularis and Ixodes pacificus ticks' range has expanded (4-6). Predictive models suggest that factors related to climate change and land use are driving changes in the epidemiology of LD (7-9).

The tick I. scapularis is the main vector in northeastern and upper midwestern United States (US) and bordering areas of Canada, while I. pacificus is the major vector in western US and western Canada $(10,11)$. The main vector in western Europe is Ixodes ricinus (3) while in eastern Europe and Asia it is I. persulcatus (12). Immature ticks (larvae and nymphs) require small to medium size vertebrates (rodents, reptiles and birds), while adult ticks feed on medium to large mammals (such as deer) $(3,13)$. Other 
human biting tick species share the same geographic location as known vectors of $B$. burgdorferi s.l.; however, these ticks are not competent vectors. Competence is established for some tick species that rarely feed upon humans (e.g., l. angustus and I. spinipalpis), but they could be contributing to the maintenance of $B$. burgdorferi s.I. transmission cycles involving other vertebrate reservoirs $(14,15)$.

In general, early symptoms of human infection include a characteristic rash, fever, headache and lethargy. If untreated with antibiotics, infection can progress to early disseminated LD (with neurological or cardiac manifestations) and then to late disseminated LD (comprised of neurological manifestations and Lyme arthritis) (16).

Lyme disease is a public health issue in Canada. The number of reported LD cases increased more than six-fold, from 144 in 2009 to 917 in 2015, mainly in Central and Eastern Canada (6). To support evidence-informed decision-making on this emerging public health issue in Canada, synthesis research was prioritized to systematically identify and summarize the global evidence on LD and B. burgdorferi s.l. epidemiology, diagnosis, prevention and control. Synthesis research methodologies include scoping reviews on broadly defined questions and systematic reviews and meta-analysis on narrowly defined questions (17-19). Synthesis research methodologies aim to identify and summarize evidence on a topic in a systematic, reproducible and updateable manner $(18,19)$. The objective of a scoping review is to identify the quantity and characteristics of research on a defined topic to understand where evidence saturation and knowledge gaps exist (20-23). The outputs from this study will identify areas where priority systematic reviews could be conducted and those requiring additional research to address knowledge gaps.

The objective of this review was developed with an expert advisory group and aimed to identify and characterize the available literature addressing the following aspects of LD that are relevant for public health: a) surveillance and monitoring to determine the extent of LD in humans and/or B. burgdorferi s.s. in vertebrate reservoirs or vectors in North America; b) evaluation of diagnostic tests; c) risk factors reported for LD in humans or exposure to $B$. burgdorferi s.l. and for the occurrence of $B$. burgdorferi s.l. in vertebrate reservoirs or vectors; d) the efficacy of public health intervention strategies to prevent and/or control LD in humans or B. burgdorferi s.l. in vertebrate reservoirs or vectors; e) North American public attitudes and/or perceptions towards LD and potential prevention and control strategies; and f) the economic burden or cost-benefit of interventions and potential prevention and control strategies.

\section{Methods}

\section{Review protocol, team and expertise}

A scoping review protocol, which is available upon request, was developed a priori to ensure the synthesis methods are reproducible and applied consistently in a manner that minimized bias. The review team consisted of individuals with multi-disciplinary expertise in epidemiology, microbiology, veterinary public health, zoonoses, knowledge synthesis and information science.

An expert advisory group of six scientists and public health professionals was established to solicit expert insight on the LD issue, the types of research available and the scope of the review. The expert input defined the literature needed for decision-making, planning and response towards preventing and mitigating the public health risks from LD. The experts were specialists in the ecology of zoonotic diseases, laboratory and field-based surveillance, emerging and vectorborne diseases, molecular biology and veterinary medicine. Input was provided through a questionnaire and consensus meeting (materials are available upon request).

\section{Review question and scope}

The scoping review question was developed using a modified version of the Cochrane PICOS/ PECOS (population, intervention/exposure, comparison, outcomes and study design) framework (17). "What is the current state of scientific knowledge on surveillance/monitoring, prevalence and incidence, societal attitudes and/or perceptions in North America and global prevention and control strategies, risk factors and diagnosis of LD in humans and B. burgdorferi s.I. in vector and vertebrate reservoirs?" The "populations" of interest were humans, vectors and vertebrate reservoirs. The "interventions/ exposures" were the major topic categories: surveillance/ monitoring, prevalence and incidence, societal attitudes and/ or perceptions in North America (Canada, US and Mexico) and global evaluation of diagnostic tests, prevention and control strategies and risk factors. The "outcomes" were LD or infection/ exposure to $B$. burgdorferi s.l. To our knowledge this is the only scoping review with a broad focus on global LD research relevant for public health; a previous scoping review focused only on research from Australia (24).

\section{Search strategy}

A comprehensive search strategy, adapted to the specific requirements of each database, was implemented without limits in the following bibliographic databases on September 13, 2013 and updated on September 27, 2016: Centre for Agriculture and Bioscience (CAB) Abstracts, Scopus, PubMed, BIOSIS, PsycINFO, APA PsycNet, Sociological Abstracts, and EconLit. These databases were chosen to ensure appropriate breadth across multiple disciplines. The original search of BIOSIS (via web of knowledge) could not be updated as the database is no longer available. The search algorithm was optimized in Scopus.

The following search terms were used: (lyme OR borrelia) AND (host OR sentinel OR landscaping OR vector OR vectors OR monitor OR monitoring OR surveillance OR reservoir OR reservoirs OR prevalence OR educate OR education OR barrier OR barriers OR intervene OR intervention OR incidence OR 
rate OR prevent OR prevention OR control OR risk OR risks OR attitude OR attitudes OR perception OR perceptions OR detection OR diagnostic).

The capacity of the electronic search to identify all relevant primary research was confirmed by hand-searching reference lists from two primary research papers $(25,26)$, Practice Guidelines by the Infectious Diseases Society of America (10), one systematic review (27), three narrative reviews (28-30) and four European conference proceedings (31-34).

A search for grey literature on the websites of government and research organizations worldwide was conducted in February 2014, to complement the electronic database search. Only government and research reports and theses/dissertations were considered for inclusion in the review as grey literature.

\section{Relevance screening and inclusion criteria}

Citation titles and abstracts were screened using an a priori designed form consisting of two questions: whether the citation described primary research on LD or B. burgdorferi s.l. and whether it was relevant to one or more aspects of the research question. Primary research was considered original research where authors generated and reported their own data. Articles in English, French and Spanish were included while other languages were excluded due to limited translation resources.

\section{Data characterization and extraction}

Complete articles of potentially relevant citations were reviewed using a data characterization and utility (DCU) form consisting of 20 questions designed a priori and available upon request. These questions aimed to confirm article relevance, data utility and allow extraction of the main article characteristics to properly classify the study methodology, population(s), laboratory tests, objectives and outcome characteristics. This could result in one study meeting one, two or more categories.

\section{Scoping review management, data charting and analysis}

The search results were imported, de-duplicated and managed in reference management software (RefWorks 2.0; ProQuest LLC, Bethesda, Maryland, US). The scoping review was managed in a web-based electronic systematic review management platform (DistillerSR, Evidence Partners, Ottawa, Ontario, Canada). Two reviewers independently completed all steps of the scoping review. Eight reviewers pre-tested the relevance screening tool with 50 abstracts (kappa>0.8) and the DCU form using three articles. Discrepancies between reviewers were examined and following discussion the form was updated to increase clarity and relevance of questions. The protocol and a reviewer guideline were used to standardize reviewer answers and help resolve conflicts. Resolution of conflicts between reviewers was reached by consensus or by consultation with a third reviewer. Data collected in the DCU form were exported into Excel spreadsheets (Microsoft Corporation, Redmond, Washington, US), formatted and analyzed descriptively (frequencies and percentages) to facilitate categorization and charting.

\section{Results}

The search identified 19,353 abstracts and titles and 4,910 full papers screened for relevance (Figure 1). The scoping review included 2,258 relevant articles (full list provided in the Supplementary References) (35). The majority of the included research was published after $1990(91.4 \% ; n=2,064)$ and of those (82.8\%; $n=1,869)$ were journal articles (Appendix 1). Included articles were in English $(n=2,241)$, French $(n=14)$ and Spanish $(n=3) ; 282$ potentially relevant articles were excluded from the review because they were in other languages (e.g., German, $n=75$ articles; Russian, $n=53$; and Polish, $n=43$ ). The excluded studies represent an unknown language bias for some focus areas: the evaluation of diagnostic tests $(n=131)$; risk factors $(n=94)$; interventions $(n=64)$; and economic evaluations of the burden of LD $(n=7)$. There was a high proportion of North American research (70.8\%; $n=1,597)$; this likely results from non-North American exclusions under surveillance and public attitudes and/or perceptions categories in addition to the language exclusions.

Figure 1: Flow diagram of articles through scoping review

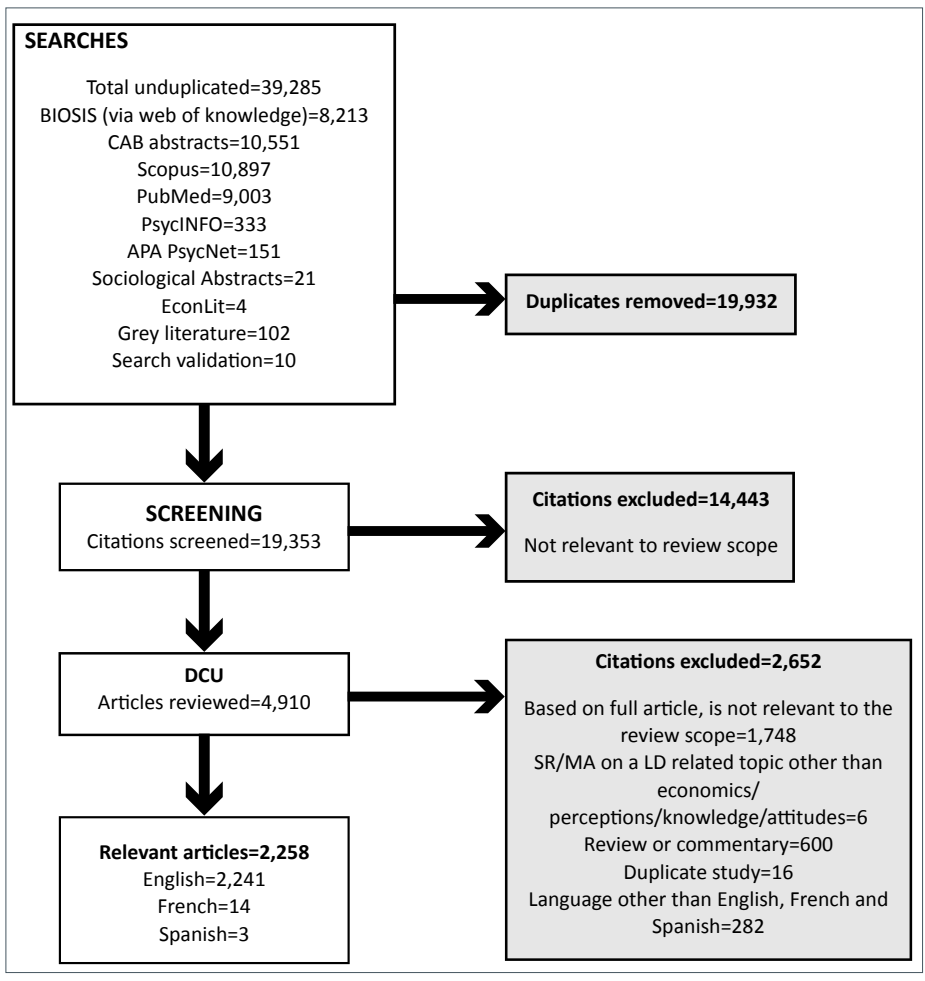

Abbreviations: $C A B$, Centre for Agriculture and Bioscience; $D C U$, data characterization and utility; LD, Lyme disease; SR/MA, systematic review/meta-analysis 
Research activity across the six focus areas has changed over time (Figure 2) starting with the earliest relevant paper by Steere et al., 1977 that described an outbreak of Lyme arthritis, mainly in children (36).

Figure 2: Bubble plot of research themes by publication year $(N=2,258)^{a, b}$

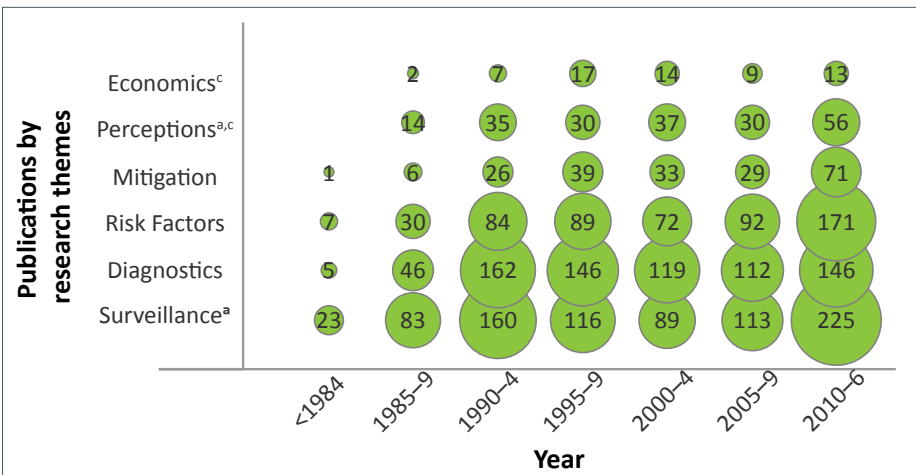

Note: Bubble plot of the major Lyme disease or B. burgdorferi s.l. research themes by publication year $(\mathrm{N}=2,258)$

Included studies are only from North America

Article may be included in more than one category, so numbers are $>2,258$

'This includes the qualitative research on the topic

Legend: The size of the bubble is proportional to the volume of research noted in each bubble

Since then, the majority of LD research has focused on surveillance $(n=809)$, diagnostic tests $(n=736)$ and identification of risk factors $(n=545)$ on all sample population categories

(Table 1). The least amount of primary research has been on the economic burden or cost-benefit of interventions for LD ( $n=32)$.

Table 1: Heat chart of the number of studies for each of the six focus areas of Lyme disease by population category $(\mathrm{N}=2,258)$

\begin{tabular}{|l|r|r|r|r|}
\hline \multicolumn{1}{|c|}{ Study focus } & $\begin{array}{c}\text { Total } \\
\text { studies }^{\mathrm{a}}\end{array}$ & $\begin{array}{r}\text { Human } \\
\text { Studies }\end{array}$ & $\begin{array}{r}\text { Vertebrate } \\
\text { reservoirs }\end{array}$ & Vectors \\
\hline $\begin{array}{l}\text { Surveillance and } \\
\text { monitoring in North } \\
\text { America }\end{array}$ & $809^{\mathrm{c}}$ & $283^{\mathrm{d}}$ & $448^{\mathrm{d}}$ & $432^{\mathrm{d}}$ \\
\hline $\begin{array}{l}\text { Accuracy of } \\
\text { diagnostic tests }\end{array}$ & $736^{\mathrm{c}}$ & $546^{\mathrm{d}}$ & $158^{\mathrm{e}}$ & $89^{\mathrm{e}}$ \\
\hline Risk factors & $545^{\mathrm{d}}$ & $262^{\mathrm{d}}$ & $202^{\mathrm{d}}$ & $297^{\mathrm{d}}$ \\
\hline $\begin{array}{l}\text { Public health } \\
\text { interventions }\end{array}$ & $205^{\mathrm{d}}$ & $72^{\mathrm{e}}$ & $98^{\mathrm{e}}$ & $106^{\mathrm{e}}$ \\
\hline $\begin{array}{l}\text { Attitudes and/or } \\
\text { perceptions in North } \\
\text { America }\end{array}$ & $202^{\mathrm{d}}$ & $202^{\mathrm{d}}$ & $0^{\mathrm{e}}$ & $0^{\mathrm{e}}$ \\
\hline $\begin{array}{l}\text { Economic burden } \\
\text { and cost-effective } \\
\text { interventions }\end{array}$ & $32^{\mathrm{b}, \mathrm{e}}$ & $32^{\mathrm{e}}$ & $0^{\mathrm{e}}$ & $0^{\mathrm{e}}$ \\
\hline
\end{tabular}

Note: Heat chart of the number of studies underpinning each of the six focus areas of Lyme disease or $B$. burgdorferi s.l. research included in this scoping review $(n=2,258)$ by population category

a Numbers do not add up horizontally or vertically to "total studies" as an article can cover two or more study themes

${ }^{b}$ These 32 are primary studies - the number in the bubble chart includes reviews and

commentaries used in the qualitative piece

Heat rate $809-736$ (red)

${ }^{d}$ Heat rate 202-546 (yellow)

Heat rate $1-158$ (green)
The 2,258 papers were compared not only by publication year (Figure 1) and study focus groups (Table 1), but also by pathogen, host and vectors (Appendix 2). The number and percentage of papers attributed to the different species of the $B$. burgdorferi s.l. complex are presented as well as the populations studied. The three most investigated human pathogens were B. burgdorferi s. $(73.7 \% ; n=1,664)$, B. afzelii (9.7\%; $n=220)$ and B. garinii (9.7\%; $n=219)$. Common host species categories included humans $(51.2 \% ; n=1,154)$, rodents $(22.5 \%$; $n=508)$ and dogs $(10.1 \% ; n=228)$. Frequently investigated vectors included I. scapularis (20.3\%; $n=459)$, I. ricinus $(6.6 \% ; n=149)$ and Dermacentor variabilis (5.0\%; $n=112$ ). Many non-lxodes tick species (e.g., D. variabilis) and one Ixodes species (I. cookei) are incompetent or inefficient vectors of B. burgdorferi s.l. (37), but were sampled and tested in studies of tick range and habitat because their range overlaps with the known vectors.

\section{Surveillance and monitoring in North America}

Epidemiological surveys or surveillance and monitoring programs (Table 2) and their results in North America represented $35.9 \%$ of articles $(n=809)$ and provided results for one or more population categories; humans with LD $12.6 \%(n=283)$ or B. burgdorferi s.s. infection in vertebrate reservoirs $(19.8 \% ; n=448)$ or vectors (19.1\%; $n=432$ ). Seven articles provided an evaluation of

Table 2: Summary of surveillance/monitoring studies in North America $(n=809)$

\begin{tabular}{|c|c|c|c|c|c|c|}
\hline \multirow{2}{*}{$\begin{array}{c}\text { Surveillance } \\
\text { type/monitoring } \\
\text { approach }\end{array}$} & \multicolumn{2}{|c|}{$\begin{array}{l}\text { Vectors } \\
(n=432)\end{array}$} & \multicolumn{2}{|c|}{$\begin{array}{l}\text { Vertebrate } \\
\text { reservoirs } \\
\quad(n=448)\end{array}$} & \multicolumn{2}{|c|}{$\begin{array}{l}\text { Humans } \\
(n=283)\end{array}$} \\
\hline & $n^{a}$ & $\%^{a}$ & $n^{a}$ & $\%^{a}$ & $n^{a}$ & $\%^{a}$ \\
\hline \multicolumn{7}{|l|}{ Active } \\
\hline Targeted sampling ${ }^{b}$ & 364 & 84.3 & 308 & 68.8 & 121 & 42.5 \\
\hline $\begin{array}{l}\text { Using sentinel } \\
\text { animals }\end{array}$ & 63 & 14.6 & 102 & 22.8 & 11 & 3.9 \\
\hline \multicolumn{7}{|l|}{ Passive } \\
\hline $\begin{array}{l}\text { Physician/ } \\
\text { veterinarian } \\
\text { reporting }\end{array}$ & 50 & 11.6 & 41 & 9.2 & 135 & 48.1 \\
\hline $\begin{array}{l}\text { Public reporting/ } \\
\text { submission }\end{array}$ & 31 & 7.2 & 21 & 4.7 & 16 & 5.6 \\
\hline $\begin{array}{l}\text { Syndromic } \\
\text { surveillance }\end{array}$ & 0 & 0.0 & 3 & 0.7 & 24 & 8.4 \\
\hline Other & 0 & 0.0 & $1^{c}$ & 0.2 & $2^{d}$ & 0.7 \\
\hline Laboratory-based & 10 & 2.3 & 24 & 5.4 & 61 & 21.4 \\
\hline $\begin{array}{l}\text { Evaluation of } \\
\text { surveillance } \\
\text { methods }\end{array}$ & 0 & 0.0 & 2 & 0.4 & 7 & 2.5 \\
\hline
\end{tabular}

Abbreviation: $\mathrm{n}$, number

Note: Summary of surveillance/monitoring approaches and surveys on the burden of LD in humans or B. burgdorferi s.s. in vectors or vertebrate reservoirs captured in the scoping review $(\mathrm{n}=809)$

Article may be included in more than one category, so numbers are $>809$ and percentages will not equal $100 \%$

b Includes both formal surveillance programs and epidemiological surveys

c Hunter-killed dee

${ }^{\mathrm{d}}$ Hospital records

e Only laboratory test submissions are identified; patients who do not seek medical attention or seek medical attention but are not tested will not be captured by this type of surveillance system 
surveillance programs for humans (38-44), two for vertebrate reservoirs $(45,46)$ and none for vector surveillance programs.

Studies include both formal surveillance programs with ongoing (routine) active collection and analysis of data, as well as epidemiological surveys that actively collect and analyse data over a specific and/or defined time period. Laboratory-based surveillance differs from population-wide surveillance and passive physician reporting schemes in that only laboratory test submissions are identified by this type of surveillance. Patients who do not seek medical attention or seek medical attention but are not tested will not be captured by this type of surveillance system.

\section{Accuracy of diagnostic tests}

A large number of studies, $32.6 \%(n=736)$, evaluated the accuracy of diagnostic and/or screening tests for $B$. burgdorferi s.l. infection or exposure (Appendix 1). Of these, 546 articles evaluated tests for humans, 158 for vertebrate reservoirs and 89 for vectors. More information on this is available in a separate publication (47).

\section{Risk factors}

Risk factors related to human or host exposure to ticks, acquiring LD in humans or B. burgdorferi s.l. infection in hosts or ticks were reported in $24.1 \%(n=545)$ of included articles (Table 3$)$. One or more risk factors were significant in most of these articles ( $n=425$ of the 545 articles). The most frequently evaluated potential risk factors were related to geography (region, type of development; 13.0\%; $n=294$ ), and landscape features (e.g., presence of leaf litter, elevation, woodland type; $9.2 \%$; $=207$ ).

Table 3: Summary of risk factors studies $(n=545)$

\begin{tabular}{|c|c|c|c|}
\hline Risk factor category ${ }^{a}$ & $\begin{array}{l}\text { Human } \\
\text { (n=262 } \\
\text { studies) }\end{array}$ & $\begin{array}{l}\text { Vertebrate } \\
\text { reservoirs } \\
\quad(n=202 \\
\text { studies) }^{a}\end{array}$ & $\begin{array}{l}\text { Vector } \\
\text { ( } n=297_{\text {studies) }^{a}}\end{array}$ \\
\hline \multicolumn{4}{|l|}{ Host demographic factors ${ }^{a}$} \\
\hline Age of cases & 111 & 66 & Life stage 14 \\
\hline Gender & 99 & 46 & 7 \\
\hline Other & $28^{b}$ & $44^{c}$ & 0 \\
\hline \multicolumn{4}{|l|}{ Human behaviours } \\
\hline Occupational risk & 108 & - & - \\
\hline $\begin{array}{l}\text { Outdoor recreational } \\
\text { activities (e.g., picnics, } \\
\text { camping) }\end{array}$ & 65 & - & - \\
\hline Pet ownership & 54 & - & - \\
\hline $\begin{array}{l}\text { History/number of tick } \\
\text { bites }\end{array}$ & 34 & - & - \\
\hline $\begin{array}{l}\text { Gardening or yard } \\
\text { work }\end{array}$ & 18 & - & - \\
\hline $\begin{array}{l}\text { Walking or jogging in } \\
\text { woods }\end{array}$ & 16 & - & - \\
\hline $\begin{array}{l}\text { Clearing brush in yard } \\
\text { during spring and } \\
\text { summer }\end{array}$ & 10 & - & \\
\hline
\end{tabular}

Table 3: (continued) Summary of risk factors studies $(n=545)$

\begin{tabular}{|c|c|c|c|}
\hline Risk factor category & $\begin{array}{l}\text { Human } \\
\text { ( } \mathrm{n}=262 \\
\text { studies) }\end{array}$ & $\begin{array}{c}\text { Vertebrate } \\
\text { reservoirs } \\
\begin{array}{c}(n=202 \\
\text { studies) }\end{array}\end{array}$ & $\begin{array}{l}\text { Vector } \\
\text { ( } n=297 \\
\text { studies) }^{a}\end{array}$ \\
\hline Other $^{d}$ & 37 & - & - \\
\hline \multicolumn{4}{|l|}{ Geographic } \\
\hline Region & 83 & 98 & 102 \\
\hline $\begin{array}{l}\text { Urban, suburban or rural } \\
\text { setting }\end{array}$ & 33 & 15 & 18 \\
\hline $\begin{array}{l}\text { Living in a single family } \\
\text { home with yards, } \\
\text { attached land or woods }\end{array}$ & 14 & 0 & 7 \\
\hline Other & $11^{e}$ & $1^{f}$ & $14^{9}$ \\
\hline Month of year & 60 & 97 & 99 \\
\hline \multicolumn{4}{|l|}{ Climate } \\
\hline Temperature & 22 & 28 & 64 \\
\hline Rainfall/precipitation & 14 & 26 & 35 \\
\hline Relative humidity & 5 & 4 & 26 \\
\hline Other & $5^{h}$ & $6^{\mathrm{i}}$ & $9 j$ \\
\hline \multicolumn{4}{|l|}{ Landscape features } \\
\hline Woodland type & 28 & 34 & 94 \\
\hline Drainage & 3 & 4 & 3 \\
\hline Vegetation type & 5 & 14 & 0 \\
\hline Birdfeeders & 5 & 0 & 2 \\
\hline Deer on properties & 15 & 4 & 10 \\
\hline Rock walls/wood piles & 4 & 1 & 3 \\
\hline Wooded properties & 9 & 0 & 4 \\
\hline Elevation/slope of land & 11 & 22 & 50 \\
\hline $\begin{array}{l}\text { Deer on residential } \\
\text { property }\end{array}$ & 4 & 0 & 8 \\
\hline $\begin{array}{l}\text { Presence of moist humus } \\
\text { and leaf litter }\end{array}$ & 8 & 4 & 17 \\
\hline Animal densities & 3 & 2 & 3 \\
\hline Other & $39^{k}$ & $31^{\prime}$ & $75^{m}$ \\
\hline
\end{tabular}

Abbreviation: $n$, number; -, not applicable

Note: Summary of risk factors investigated for human exposure to ticks or acquisition of Lyme disease, vertebrate reservoir exposure to ticks and B. burgdorferi s.l. infection in vertebrate reservoirs or ticks $(n=545)$

reservoirs or ticks $(n=545$ )
a Multiple answers were allowed per article in some categories so the sum of articles across risk factor categories is $>545$

${ }^{b}$ Includes household income, race, education and duration of residency

' Includes specificity for a Borellia sp., species, body size and breed

d Includes history of travel to tick-endemic areas, contact with animals, co-morbidities/infections, blood transfusions, pregnancy/fetal exposure, smoking and engagement in at-risk behaviors for

tick bites
e Includes different habitats/ecosystems, size of area, proximity of residence or sites, entomologic risk index, residential development within recently reforested suburban areas and low density residential development

Woodland vs household habitats

9 Includes attitude and longitude, different habitats, zones with different deer densities, size and recently deforested

h Includes type of climate, air pressure and wind speed, monthly soil moisture and growing days 1 Includes growing days and snow depth

i Includes saturation deficit, snow cover, Mediterranean climate, wind conditions, solar insolation, North Atlantic Oscillation indices, light intensity, cool moist winters and warm dry summers ${ }^{k}$ Includes forest cover, proximity to woods, vegetation type, patch size, weeds in yard, vegetable garden, playscapes, fencing, presence of lizards, beaches or dunes

'Includes vegetation type, soil characteristics, maturity of trees, land use, impact of sudden oak death, vegetation index, presence of lizards and patch size

${ }^{m}$ Landscape features (vectors) other: habitat type, forest fragmentation, vegetation index, maturity of trees, land use, patch size, soil characteristics, proximity to forest, impact of sudden oak death, downed wood, beaches or dunes, forestry, density of trees, plant biomass, playscapes, property size 
Many studies examined human risk factors related to high risk behaviours (e.g., walking in the woods and gardening; $n=32$ ) and demographics (e.g., age and gender; $\mathrm{n}=213$ ).

\section{Public health interventions}

Intervention efficacy to prevent tick exposure, LD in humans or B. burgdorferi s.l. infection in vertebrate reservoirs or vectors was reported in $9.1 \%(n=205)$ of included articles. Vaccination (3.5\%; $n=78)$, was the most evaluated type of intervention for humans $(n=26)$, dogs $(n=25)$, horses $(n=1)$ or animal models using rodents, birds, chickens, embryonated chicken eggs and Rhesus monkeys $(n=28)$ (Table 4). Chemical control measures were reported in $2.5 \%(n=56)$ of articles, including treatment of vertebrate hosts, use of persistent acaricides and spraying of acaricides or desiccants on vegetation. A range of personal protective measures for humans were also evaluated in $2.7 \%$ of articles $(n=62)$.

Table 4: Summary of intervention categories $(n=205)$

\begin{tabular}{|c|c|c|}
\hline Intervention & $\mathrm{n}^{\mathrm{a}}$ & $\%^{a}$ \\
\hline \multicolumn{3}{|l|}{ Vaccination } \\
\hline Vaccination of humans & 26 & 12.7 \\
\hline Dogs & 25 & 12.2 \\
\hline Horses & 1 & 0.5 \\
\hline Animal models for vaccine development ${ }^{b}$ & 28 & 13.7 \\
\hline \multicolumn{3}{|l|}{ Chemical control measures } \\
\hline Use of persistent acaricides & 17 & 8.3 \\
\hline Rodent-targeted tick-control device use & 15 & 7.3 \\
\hline $\begin{array}{l}\text { Spray or broadcast acaricides or } \\
\text { desiccants to vegetation }\end{array}$ & 13 & 6.3 \\
\hline Other ${ }^{c}$ & 11 & 5.4 \\
\hline Personal protective measures for humans ${ }^{d}$ & 62 & 30.2 \\
\hline $\begin{array}{l}\text { Public education to decrease risk of Lyme } \\
\text { disease infection }\end{array}$ & 19 & 9.3 \\
\hline Landscape features and modifications ${ }^{e}$ & 18 & 8.8 \\
\hline Other $^{f}$ & 28 & 13.7 \\
\hline
\end{tabular}

Abbreviation: $n$, number

Note: Summary of intervention categories that were evaluated for the prevention of tick exposure or LD in humans or B. burgdorferi s.l. infection in vertebrate hosts or vectors $(n=205)$

a Article may be included in more than one category so numbers are $>205$ and percentages will not equal $100 \%$

Includes rodents, birds, embryonated chicken eggs and Rhesus monkeys

c Includes treatment of tick hosts with acaricides

Includes checking for ticks during/after outdoor activity, wearing long pants and/or

lightly-coloured clothing or clothing treated with permethrin insecticide, wearing repellents, avoidance of high risk areas, tucking pants into socks, bathing after spending time outdoors, wear long-sleeved shirt/hat and parental skin inspection

e Includes fencing, burning/clearing vegetation, frequent mowing, leaf-litter clearing, small scale landscaping, branch trimming, presence of a mulch or gravel dry barrier where lawns abut woods ${ }^{f}$ Includes culling deer, biological control of ticks, prophylaxis for humans, checking pets for ticks, unspecified interventions to lower tick abundance, removal of lizards, orally administering an antibiotic to rodents

Attitudes and/or perceptions in North America Public knowledge, attitudes and/or perceptions towards LD and potential prevention and control strategies in North America were reported in $8.9 \%(n=202)$ articles. The general public $(n=68)$ and/or physicians $(n=32)$ were usually the target populations and the research aim was to assess knowledge of LD $(n=131)$, perception of severity and vulnerability to $L D(n=73)$, protective/risky behaviors $(n=73)$ and knowledge and attitudes towards protection measures $(n=56)$ (Table 5$)$. Within this literature, there are examples of how well-designed and relatively

Table 5: Articles reporting on public knowledge, attitudes or perceptions in North America $(n=202)$

\begin{tabular}{|c|c|c|}
\hline Characteristic & $\mathrm{n}$ & $\begin{array}{c}\%^{a} \\
(n=202)\end{array}$ \\
\hline \multicolumn{3}{|l|}{ Publication date } \\
\hline Before 1990 & 14 & 6.9 \\
\hline 1990-1994 & 35 & 17.3 \\
\hline 1995-1999 & 30 & 14.9 \\
\hline $2000-2004$ & 37 & 18.3 \\
\hline $2005-2009$ & 30 & 14.9 \\
\hline$>2010$ & 56 & 27.7 \\
\hline \multicolumn{3}{|l|}{ Document type } \\
\hline Journal article & 137 & 67.8 \\
\hline Book chapter & 16 & 7.9 \\
\hline Other $^{\mathrm{b}}$ & 49 & 24.3 \\
\hline \multicolumn{3}{|l|}{ Study type } \\
\hline Primary research, quantitative & 76 & 37.6 \\
\hline Primary research, qualitative & 8 & 4.0 \\
\hline Primary research, mixed methods & 3 & 1.5 \\
\hline Book chapter/review/commentary & 115 & 56.9 \\
\hline \multicolumn{3}{|l|}{ Study design } \\
\hline Observational study & 74 & $85.1^{\circ}$ \\
\hline Cross-sectional & 66 & 75.9 \\
\hline Cohort & 2 & 2.3 \\
\hline Case-control & 2 & 2.3 \\
\hline Prevalence survey & 3 & 3.4 \\
\hline Surveillance or monitoring program & 1 & 1.1 \\
\hline Experimental study & 9 & 10.3 \\
\hline Controlled trial & 7 & 8.0 \\
\hline Quasi experiment & 2 & 2.3 \\
\hline Qualitative study & 6 & 6.9 \\
\hline Mixed methods & 1 & 1.1 \\
\hline \multicolumn{3}{|l|}{ Study location } \\
\hline United States & 182 & 90.1 \\
\hline Canada & 27 & 13.4 \\
\hline \multicolumn{3}{|c|}{ Stakeholder populations investigated for contextual information } \\
\hline General public & 68 & 33.7 \\
\hline Physicians & 32 & 15.8 \\
\hline Other medical or public health professionals & 16 & 7.9 \\
\hline Lyme disease experts/researchers & 12 & 5.9 \\
\hline Government personnel & 9 & 4.5 \\
\hline Children/students & 7 & 3.5 \\
\hline Outdoor workers & 6 & 3.0 \\
\hline Veterinarians & 3 & 1.5 \\
\hline Other $^{d}$ & 11 & 5.4 \\
\hline \multicolumn{3}{|l|}{ Method of contextual data collection } \\
\hline Quantitative questionnaire or survey & 75 & 37.1 \\
\hline Analysis of documents & 25 & 12.4 \\
\hline Qualitative interview & 15 & 7.4 \\
\hline Othere & 18 & 8.9 \\
\hline
\end{tabular}




\section{SCOPING REVIEW}

Table 5: (continued) Articles reporting on public knowledge, attitudes or perceptions in North America $(n=202)$

\begin{tabular}{|l|r|r|}
\hline \multicolumn{1}{|c|}{ Characteristic } & $n$ & $\begin{array}{c}\text { \% } \\
\text { (n=202) }\end{array}$ \\
\hline Not specified & 48 & 23.8 \\
\hline Article focus & 131 & 64.9 \\
\hline Knowledge & 73 & 36.1 \\
\hline Severity/vulnerability & 73 & 36.1 \\
\hline Behaviours & 56 & 27.7 \\
\hline Efficacy of protection measures & 43 & 21.3 \\
\hline Other & \multicolumn{3}{|c|}{} \\
\hline Theories of human behaviour used to inform data collection \\
\hline Health belief model & 17 & 8.4 \\
\hline Other' & 18 & 8.9 \\
\hline Formats used to report quantitative study results & 33 & 16.3 \\
\hline Prevalence & 27 & 13.4 \\
\hline Measures of association & 22 & 10.9 \\
\hline Ordinal/Likert scale & 19 & 9.4 \\
\hline Model & 18 & 8.9 \\
\hline 2 x 2 data & 11 & 5.4 \\
\hline Continuous outcome & 12 & 5.9 \\
\hline Non extractable & 59 & 29.2 \\
\hline Need for additional studies & & \\
\hline \hline
\end{tabular}

Abbreviation: $\mathrm{n}$, number

Note: Articles reporting on public knowledge, attitudes or perceptions towards Lyme disease or prevention and control strategies in North America $(n=202)$

a Article may be included in more than one category so percentages will not equal $100 \%$

${ }^{b}$ Includes newspaper, letter to the editor, abstract, thesis, commentary/editorial, government or research report, conference summary, workshop report, poster/slide deck/presentation, book, meeting report and guidelines

c Percent of primary research articles $(n=87)$

Includes non-governmental organization personnel, Lyme patients, immigrants,

nursery/landscape employees, media, nudists and pet owners

- Includes conference/workshop discussion notes, author's opinion/commentary, focus groups, patient diaries and educational intervention

${ }^{f}$ Includes vaccination, diagnosis/tests, willingness to pay for protection, Lyme politics/media, patient advocacy/experience, guidelines, expert opinion of risk factors, trust in doctors, and toxic or environmental effects of control measures

9 Includes theory of planned behaviour, behaviour motivation, social learning theory (risk compensation, accuracy hypothesis, risk reappraisal hypothesis, preventative belief model, social cognition theory, experimental learning loop, motivated reasoning, dual-processing models, attribution of responsibility)

inexpensive health education messages, grounded on social learning theory, can result in increased protective behaviors and a reduced rate of LD (48-53).

\section{Economic burden and cost-effective interventions}

Primary studies of the economic burden of LD or cost-benefit of interventions were reported in $1.4 \%(n=32)$ of the articles. These included analysis of the cost of diagnostic tests for LD, health care costs for patients and cost of particular interventions.

\section{Discussion}

This scoping review provides an assessment of the quantity and characteristics of the global evidence for six focus areas of LD and $B$. burgdorferi s.l. research on humans, vertebrate reservoirs and vectors, which included surveillance and monitoring in North America, evaluation of diagnostic tests, risk factors, interventions, public attitudes and perceptions in North America and the economic burden or cost benefit of public health interventions.

\section{Knowledge saturation and gaps}

Research and surveillance data have been consistently collected throughout North America since 1995. Most of LD in humans are from passive surveillance of LD case information. A smaller group of epidemiological studies examined exposure to $B$. burgdorferi s.s. by screening apparently healthy populations. Together these data provide some indication of how much exposure is occurring in areas where I. scapularis and other competent vectors have become established and where $B$. burgdorferi s.s. circulates. Additionally, epidemiological surveys were frequently conducted to evaluate $B$. burgdorferi s.s. in vertebrate reservoirs and vectors as opposed to data collected through a surveillance program. This information is key to identifying geographic risk status for public health, which aids in the diagnosis of LD in humans and decision-making on appropriate prevention and control strategies $(4,54)$. Identification of $B$. burgdorferi s.s. in vectors and vertebrates also leads to experimental studies to establish competence for transmission and the role different species may play in the maintenance and spread of B. burgdroferi s.s. and how this may change the risk of human exposure to B. burgdorferi s.s. in different areas. There is sufficient evidence to conduct a systematic review on the historical evidence of the burden of LD and B. burgdorferi s.s. in North America, which would allow an examination of how this changes over time. Some knowledge gaps were also noted pertaining to research on the role of migratory birds in the spread of $B$. burgdorferi s.s. to new areas. The contribution of potential vectors and vertebrate reservoirs to the transmission of $B$. burgdorferi s.s. has not been established for all species.

The recommended protocol for LD diagnosis is based on clinical symptoms, a history of exposure to infected ticks and/ or travel to an endemic area, which may also be supplemented by diagnostic testing (55). Recommended diagnostic testing in Canada, the US and most European countries includes a two-tiered serologic testing protocol where a positive or equivocal enzyme immunoassay (EIA) screening test is followed by a confirmatory Western blot (55-58). Improvements to LD diagnostic tests, particularly improved sensitivity for testing early stages of LD, is an active research area. Thus, periodic updates to the two recently published systematic reviews on the accuracy of diagnostic tests for humans in North America, prioritized from this scoping review, and Europe is warranted $(47,59)$.

There are many parallels between the significant risk factors studied and the intervention strategies evaluated, particularly for human personal protective measures and outcomes of tick presence or risk of tick exposure and landscape modification. Overall, the quantity of research on each risk factor or intervention was quite small; most authors highlighted additional needed research. Even though there may not be a lot of 
research, systematic reviews summarizing evidence on significant risk factors and intervention efficacy would be useful for the development of new prevention and education strategies for public health. Vaccination was the only intervention category for which there were many studies evaluating potential or commercial vaccines for humans, dogs or horses. No further work on this topic is warranted as a systematic review was recently published (60). Lyme vaccines are currently approved and used in dogs, and there has not been a commercial vaccine available for humans since the withdrawal of LYMErix in 2002 (61-64).

Research estimating the economic impact of LD or public attitudes and perceptions compliment many of the other research focuses. Where economic information is useful in placing an issue on the public health agenda and for the justification of allocated resources $(1,65)$, understanding the drivers and barriers to behavior change can determine the success of a public education intervention. This review captured several different types of economic models and data that could be used as a framework to estimate the cost of LD or other outcomes using local cost estimates. Similarly, research investigating public attitudes and/or perceptions towards LD and potential prevention and control strategies provides an in depth understanding of the context and would be a complimentary addition to results from systematic reviews of public health interventions. These include evaluations of knowledge, attitudes, willingness to pay and the impact of public programs on behaviour (e.g., the use of personal protective measures) (26). Several limitations to this research exist: few studies were based on a model of human behavior change, studies were small thus less generalizable and surrogate and subjective outcome measures for behavior change were often used due to difficulties in obtaining objective measurements (66-68).

\section{Limitations of study}

Limitations to this scoping review include the language bias noted above and the potential for publication bias if all relevant research is not identified; the impact of these biases on the review results is largely unknown. There may also be limitations in the utility of the review due to the scope, but this depends on the needs of the end user.

This review focuses on the utility of evidence from each focus area and highlights where there is knowledge saturation and gaps in the literature.

\section{Conclusion}

This scoping review is an evidence-informed overview of the quantity and characteristics of the research underpinning each focus area; surveillance and monitoring, diagnostic tests, risk factors, interventions, attitudes and perceptions and economic research on LD and B. burgdorferi s.I. in humans, vertebrate reservoirs and vectors. The review provides a very broad understanding of what is known and unknown on this topic at this time and the identified knowledge gaps can be used to prioritize funding for future research. The searchable database created during this scoping review will facilitate addressing both anticipated and unanticipated questions using a systematic review methodology along timelines that are more conducive to decision-making, which is only possible because the relevant research has already been identified and characterized. Thus, several systematic reviews (e.g., on risk factors and interventions for each study population) could be undertaken to provide evidence-informed summaries of information on LD and $B$. burgdorferi s.l. where estimates of specific outcomes are needed for decision-making.

\section{Authors' statement}

JG - Conceptualization, methodology, formal analysis, investigation, data collection and curation, writing-original draft, review and editing, visualization, supervision, project administration

IY - Conceptualization, methodology, investigation, review and editing, visualization

$\mathrm{SH}$ - Formal analysis, investigation, data collection and curation, review and editing, visualization

MM - Investigation, data collection and curation, writing-review and editing LW - Conceptualization, methodology, formal analysis, investigation, data collection and curation, writing-original draft, writing-review and editing, visualization

\section{Conflict of interest}

None.

\section{Acknowledgements}

We thank Janet Harris and the Public Health Agency of Canada library staff for procurement of articles and Drs. Carl Uhland, Lea Nogueira-Borden and Malcolm Weir for assistance conducting relevance screening and data characterization. Thank you to our expert LD Advisory Group who helped determine and validate the scope of the project. Thank you to Drs. Nicholas Ogden, Robbin Lindsay and Pascal Michel for their expertise which they contributed to this project.

\section{Funding}

This work was supported by the Public Health Agency of Canada.

\section{References}

1. van den Wijngaard CC, Hofhuis A, Harms MG, Haagsma JA, Wong A, de Wit GA, Havelaar AH, Lugnér AK, Suijkerbuijk AW, van Pelt W. The burden of Lyme borreliosis expressed in disability-adjusted life years. Eur J Public Health 2015 Dec;25(6):1071-8. http://dx.doi.org/10.1093/ 
eurpub/ckv091. PubMed (https://www.ncbi.nlm.nih. gov/entrez/query.fcgi?cmd=Retrieve \&db=PubMed\&lis t_uids=26082446\&dopt=Abstract).

2. Becker NS, Margos G, Blum H, Krebs S, Graf A, Lane RS, Castillo-Ramírez S, Sing A, Fingerle V. Recurrent evolution of host and vector association in bacteria of the Borrelia burgdorferi sensu lato species complex. BMC Genomics 2016 Sep;17(1):734. http://dx.doi.org/10.1186/ s12864-016-3016-4. PubMed (https://www.ncbi.nlm.nih. gov/entrez/query.fcgi?cmd=Retrieve \&db=PubMed\&lis t_uids $=27632983 \&$ dopt $=$ Abstract)

3. Piesman J, Gern L. Lyme borreliosis in Europe and North America. Parasitology 2004;129 Suppl:S191-220. http:// dx.doi.org/10.1017/S0031182003004694. PubMed (https:// www.ncbi.nlm.nih.gov/entrez/query.fcgi?cmd=Retrieve \&db= PubMed\&list_uids=15938512\&dopt=Abstract)

4. Ogden NH, Lindsay LR, Morshed M, Sockett PN, Artsob H. The emergence of Lyme disease in Canada. CMAJ 2009 Jun;180(12):1221-4. http://dx.doi.org/10.1503/ cmaj.080148. PubMed (https://www.ncbi.nlm.nih.gov/ entrez/query.fcgi?cmd=Retrieve\&db=PubMed\&list_ uids $=19506281 \&$ dopt $=$ Abstract)

5. Hamer SA, Tsao JI, Walker ED, Hickling GJ. Invasion of the lyme disease vector Ixodes scapularis: implications for Borrelia burgdorferi endemicity. EcoHealth 2010 Aug;7(1):47-63. http://dx.doi.org/10.1007/s10393010-0287-0. PubMed (https://www.ncbi.nlm.nih.gov/ entrez/query.fcgi?cmd=Retrieve\&db=PubMed\&list_ uids=20229127\&dopt=Abstract)

6. Gasmi S, Ogden NH, Lindsay LR, Burns S, Fleming S, Badcock J, Hanan S, Gaulin C, Leblanc MA, Russell C, Nelder M, Hobbs L, Graham-Derham S, Lachance L, Scott AN, Galanis E, Koffi JK. Surveillance for Lyme disease in Canada: 2009-2015. Can Commun Dis Rep 2017 Oct;43(10):194-9. http://dx.doi.org/10.14745/ccdr. v43i10a01

7. Brownstein JS, Holford TR, Fish D. Effect of climate change on Lyme disease risk in North America. EcoHealth 2005 Mar;2(1):38-46. http://dx.doi.org/10.1007/s10393004-0139-x. PubMed (https://www.ncbi.nlm.nih.gov/ entrez/query.fcgi?cmd=Retrieve\&db=PubMed\&list_ uids $=19008966 \&$ dopt $=$ Abstract)

8. Ogden NH, Radojevic M, Wu X, Duvvuri VR, Leighton PA, Wu J. Estimated effects of projected climate change on the basic reproductive number of the Lyme disease vector Ixodes scapularis. Environ Health Perspect 2014 Jun;122(6):631-8. 10.1289/ehp.1307799. PubMed (https://www.ncbi.nlm. nih.gov/entrez/query.fcgi?cmd=Retrieve \&db=PubMed\&li st_uids=24627295\&dopt=Abstract)

9. Gray JS, Dautel H, Estrada-Peña A, Kahl O, Lindgren E. Effects of climate change on ticks and tick-borne diseases in europe. Interdiscip Perspect Infect Dis 2009;2009:593232. http://dx.doi.org/10.1155/2009/593232. PubMed (https:// www.ncbi.nlm.nih.gov/entrez/query.fcgi?cmd=Retrieve\&db= PubMed\&list_uids=19277106\&dopt=Abstract)
10. Gray JS. Review The ecology of ticks transmitting Lyme borreliosis. Exp Appl Acarol 1998;22(5):249-58. http:// dx.doi.org/10.1023/A:1006070416135

11. Nelder MP, Russell C, Lindsay LR, Dhar B, Patel SN, Johnson S, Moore S, Kristjason E, Li Y, Ralevski F. Population-based passive tick surveillance and detection of expanding foci of blacklegged ticks Ixodes scapularis and the Lyme disease agent Borrelia burgdorferi in Ontario, Canada. PLoS One 2014 Aug;9(8):e105358. http://dx.doi.org/10.1371/ journal.pone.0105358. PubMed (https://www.ncbi.nlm. nih.gov/entrez/query.fcgi?cmd=Retrieve \&db=PubMed\&li st_uids=25171252\&dopt=Abstract)

12. Cao WC, Zhao QM, Zhang PH, Yang H, Wu XM, Wen $\mathrm{BH}$, Zhang XT, Habbema JD. Prevalence of Anaplasma phagocytophila and Borrelia burgdorferi in Ixodes persulcatus ticks from northeastern China. Am J Trop Med Hyg 2003 May;68(5):547-50. http://dx.doi.org/10.4269/ ajtmh.2003.68.547. PubMed (https://www.ncbi.nlm.nih. gov/entrez/query.fcgi?cmd=Retrieve $\& d b=$ PubMed\&lis t_uids=12812342\&dopt=Abstract)

13. Mead PS. Epidemiology of Lyme disease. Infect Dis Clin North Am 2015 Jun;29(2):187-210. http://dx.doi. org/10.1016/j.idc.2015.02.010. PubMed (https://www.ncbi. $\mathrm{nlm}$.nih.gov/entrez/query.fcgi?cmd=Retrieve \&db=PubMed\&l ist_uids=25999219\&dopt=Abstract)

14. Banerjee SN, Banerjee M, Smith JA, Fernando K. Lyme disease in British Columbia - An update. BCMJ 1994;36:5401.

15. Brown RN, Peot MA, Lane RS. Sylvatic maintenance of Borrelia burgdorferi (Spirochaetales) in Northern California: untangling the web of transmission. J Med Entomol 2006 Jul;43(4):743-51. http://dx.doi.org/10.1093/ jmedent/43.4.743. PubMed (https://www.ncbi.nlm.nih. gov/entrez/query.fcgi?cmd=Retrieve $\& \mathrm{db}=$ PubMed\&lis t_uids=16892634\&dopt=Abstract)

16. Wormser GP, Dattwyler RJ, Shapiro ED, Halperin JJ, Steere AC, Klempner MS, Krause PJ, Bakken JS, Strle F, Stanek G, Bockenstedt L, Fish D, Dumler JS, Nadelman RB. The clinical assessment, treatment, and prevention of lyme disease, human granulocytic anaplasmosis, and babesiosis: clinical practice guidelines by the Infectious Diseases Society of America [Erratum in: Clin Infect Dis. 2007 Oct;45] [7]. Clin Infect Dis 2006 Nov;43(9):1089-134. http://dx.doi. org/10.1086/508667. PubMed (https://www.ncbi.nlm.nih. gov/entrez/query.fcgi?cmd=Retrieve\&db=PubMed\&lis t_uids=17029130\&dopt=Abstract)

17. Higgins JP, Green S, editors. Cochrane Handbook for Systematic Reviews of Interventions: Version 5.1.0. The Cochrane Collaboration; 2011.

18. Tricco AC, Tetzlaff J, Moher D. The art and science of knowledge synthesis. J Clin Epidemiol 2011 Jan;64(1):11-20. http://dx.doi.org/10.1016/j.jclinepi.2009.11.007

19. Young I, Waddell L, Sanchez J, Wilhelm B, McEwen SA, Rajić A. The application of knowledge synthesis methods in agri-food public health: recent advancements, challenges and opportunities. Prev Vet Med 2014 Mar;113(4):339-55. 
http://dx.doi.org/10.1016/j.prevetmed.2013.11.009. PubMed (https://www.ncbi.nlm.nih.gov/entrez/query.fcgi?cmd=Retrie ve $\& \mathrm{db}=$ PubMed\&list_uids $=20189767 \&$ dopt=Abstract)

20. Arksey H, O’Malley L. Scoping studies: towards a methodological framework. Int J Soc Res Methodol 2005;8(1):19-32. http://dx.doi.org/10.1080/13645570320001 19616.

21. Levac D, Colquhoun H, O'Brien KK. Scoping studies: advancing the methodology. Implement Sci 2010 Sep;5:69. http://dx.doi.org/10.1186/1748-5908-5-69. PubMed (https:// www.ncbi.nlm.nih.gov/entrez/query.fcgi?cmd=Retrieve\&db= PubMed\&list_uids=20854677\&dopt=Abstract)

22. Colquhoun HL, Levac D, O'Brien KK, Straus S, Tricco AC, Perrier L, Kastner M, Moher D. Scoping reviews: time for clarity in definition, methods, and reporting. J Clin Epidemiol 2014 Dec;67(12):1291-4. http://dx.doi.org/10.1016/j. jclinepi.2014.03.013. PubMed (https://www.ncbi.nlm.nih. gov/entrez/query.fcgi?cmd=Retrieve \&db=PubMed\&lis t_uids $=25034198 \& d o p t=$ Abstract)

23. Pham MT, RajićA, Greig JD, Sargeant JM, Papadopoulos A, McEwen SA. A scoping review of scoping reviews: advancing the approach and enhancing the consistency. Res Synth Methods 2014 Dec;5(4):371-85. http://dx.doi. org/10.1002/jrsm.1123. PubMed (https://www.ncbi.nlm. nih.gov/entrez/query.fcgi?cmd=Retrieve\&db=PubMed\&li st_uids=26052958\&dopt=Abstract)

24. Chalada MJ, Stenos J, Bradbury RS. Is there a Lyme-like disease in Australia? Summary of the findings to date. One Health 2016 Apr;2:42-54. http://dx.doi.org/10.1016/j. onehlt.2016.03.003. PubMed (https://www.ncbi.nlm.nih. gov/entrez/query.fcgi?cmd=Retrieve\&db=PubMed\&lis t_uids=28616477\&dopt=Abstract)

25. Connally NP, Durante AJ, Yousey-Hindes KM, Meek JI, Nelson RS, Heimer R. Peridomestic Lyme disease prevention: results of a population-based case-control study. Am J Prev Med 2009 Sep;37(3):201-6. http://dx.doi.org/10.1016/j. amepre.2009.04.026. PubMed (https://www.ncbi.nlm.nih. gov/entrez/query.fcgi?cmd=Retrieve\&db=PubMed\&lis t_uids $=19595558 \&$ dopt $=$ Abstract)

26. Beaujean DJ, Bults M, van Steenbergen JE, Voeten HA. Study on public perceptions and protective behaviors regarding Lyme disease among the general public in the Netherlands: implications for prevention programs. BMC Public Health 2013 Mar;13:225. http://dx.doi. org/10.1186/1471-2458-13-225. PubMed (https://www.ncbi. nlm.nih.gov/entrez/query.fcgi?cmd=Retrieve\&db=PubMed\&l ist_uids=23497311\&dopt=Abstract)

27. Mowbray F, Amlôt R, Rubin GJ. Ticking all the boxes? A systematic review of education and communication interventions to prevent tick-borne disease. Vector Borne Zoonotic Dis 2012 Sep;12(9):817-25. http://dx.doi. org/10.1089/vbz.2011.0774. PubMed (https://www.ncbi.nlm. nih.gov/entrez/query.fcgi?cmd=Retrieve\&db=PubMed\&li st_uids=22607072\&dopt=Abstract)

28. Gray J. Risk assessment in Lyme borreliosis. Wien Klin Wochenschr 1999 Dec;111(22-23):990-3. PubMed (https://
www.ncbi.nlm.nih.gov/entrez/query.fcgi?cmd=Retrieve\&db= PubMed\&list_uids=10666816\&dopt=Abstract)

29. Nardelli DT, Munson EL, Callister SM, Schell RF. Human Lyme disease vaccines: past and future concerns. Future Microbiol 2009 May;4(4):457-69. http://dx.doi. org/10.2217/fmb.09.17. PubMed (https://www.ncbi.nlm. nih.gov/entrez/query.fcgi?cmd=Retrieve \&db=PubMed\&li st_uids $=19416014 \&$ dopt $=$ Abstract)

30. Eisen RJ, Eisen L, Ogden NH, Beard CB. Linkages of weather and climate with Ixodes scapularis and Ixodes pacificus (Acari: Ixodidae), enzootic transmission of Borrelia burgdorferi, and Lyme disease in North America. J Med Entomol 2016 Mar;53(2):250-61. http://dx.doi. org/10.1093/jme/tjv199. PubMed (https://www.ncbi.nlm. nih.gov/entrez/query.fcgi?cmd=Retrieve \&db=PubMed\&li st_uids $=26681789 \& d o p t=$ Abstract)

31. German Society of Hygiene and Microbiology. Abstracts of the 55th Meeting of the German Society of Hygiene and Microbiology. 28 September-1 October 2003, Dresden. Int J Med Microbiol 2003 Sep;293 Suppl 36:89-471. PubMed (https://www.ncbi.nlm.nih.gov/entrez/query.fcgi?cmd=Retrie ve\&db=PubMed\&list_uids=14708563\&dopt=Abstract)

32. VII International Potsdam Symposium on Tick-borne Diseases (IPS-VII), 2003: Scientific programme. www.bfr.bund.de/ cm/343/ips_vii_programm_zeitenfinal.pdf

33. Polish Epidemiologic Societies and Infectious Disease Physicians. [Abstracts of the XVII General Polish Congress, Polish Epidemiologic Societies and Infectious Disease Physicians, 14-16 September 2006, Warsaw, Poland]. Przegl Epidemiol 2006;60 Suppl 2:7-167. PubMed (https://www. ncbi.nlm.nih.gov/entrez/query.fcgi?cmd=Retrieve\&db=PubM ed\&list_uids=17315332\&dopt=Abstract)

34. Polish Epidemiologic Societies and Infectious Disease Physicians. 50th Anniversary of the Polish Society of Epidemiology and Infectious Diseases, Scientific Workshop "The Man Facing Infectious Diseases" Bydgoszcz, 13-15 September 2007). Przegl Epidemiol 2007;61:1-175.

35. Greig JD, Young I, Harding S, Mascarenhas M, Waddell LA. Lyme disease scoping review- Supplemental materials. Web Exclusive. Can Commun Dis Rep 2018;44(10). https://www. canada.ca/en/public-health/services/reports-publications/ canada-communicable-disease-report-ccdr/monthlyissue/2018-44/issue-10-october-4-2018/article-3a-lymedisease-supplementary-references-2018.html

36. Steere AC, Malawista SE, Snydman DR, Shope RE, Andiman WA, Ross MR, Steele M. Lyme arthritis: an epidemic of oligoarticular arthritis in children and adults in three connecticut communities. Arthritis Rheum 1977 Jan-Feb;20(1):7-17. http://dx.doi.org/10.1002/ art.1780200102. PubMed (https://www.ncbi.nlm.nih. gov/entrez/query.fcgi?cmd=Retrieve\& $\mathrm{db}=$ PubMed\&lis t_uids $=836338 \&$ dopt=Abstract)

37. Barker IK, Lindsay LR, Campbell GD, Surgeoner GA, McEwen SA. The groundhog tick Ixodes cookei (Acari: ixodidae): a poor potential vector of Lyme borreliosis. J Wildl Dis 1993 Jul;29(3):416-22. http://dx.doi.org/10.7589/0090- 
3558-29.3.416. PubMed (https://www.ncbi.nlm.nih. gov/entrez/query.fcgi?cmd=Retrieve\&db=PubMed\&lis t_uids=8355343\&dopt=Abstract)

38. Naleway AL, Belongia EA, Kazmierczak JJ, Greenlee RT, Davis JP. Lyme disease incidence in Wisconsin: a comparison of state-reported rates and rates from a population-based cohort. Am J Epidemiol 2002 Jun;155(12):1120-7. http:// dx.doi.org/10.1093/aje/155.12.1120. PubMed (https://www. ncbi.nlm.nih.gov/entrez/query.fcgi?cmd=Retrieve\&db=PubM ed\&list_uids=12048226\&dopt=Abstract)

39. McHugh LA, Semple S, Sorhage FE, Tan CG, Langer AJ; Centers for Disease Control and Prevention (CDC). Effect of electronic laboratory reporting on the burden of lyme disease surveillance--New Jersey, 2001-2006. MMWR Morb Mortal Wkly Rep 2008 Jan;57(2):42-5. PubMed (https://www. ncbi.nlm.nih.gov/entrez/query.fcgi?cmd=Retrieve\&db=PubM ed\&list_uids=18199968\&dopt=Abstract)

40. Schiffman EK, McLaughlin C, Ray JA, Kemperman MM, Hinckley AF, Friedlander HG, Neitzel DF. Underreporting of Lyme and other tick-borne diseases in residents of a high-incidence county, Minnesota, 2009. Zoonoses Public Health 2018 Mar;65(2):230-7. https://dx.doi. org/10.1111/zph.12291. PubMed (https://www.ncbi.nlm. nih.gov/entrez/query.fcgi?cmd=Retrieve \&db=PubMed\&li st_uids=27390047\&dopt=Abstract)

41. Ertel SH, Nelson RS, Cartter ML. Effect of surveillance method on reported characteristics of Lyme disease, Connecticut, 1996-2007. Emerg Infect Dis 2012 Feb;18(2):242-7. http://dx.doi.org/10.3201/ eid1802.101219. PubMed (https://www.ncbi.nlm.nih. gov/entrez/query.fcgi?cmd=Retrieve\&db=PubMed\&lis t_uids=22304873\&dopt=Abstract)

42. Robinson S. Lyme disease in Maine: a comparison of NEDSS surveillance data and Maine Health Data Organization hospital discharge data. Online J Public Health Inform 2014 Feb;5(3):e231-41. http://dx.doi.org/10.5210/ ojphi.v5i3.4990. PubMed (https://www.ncbi.nlm.nih. gov/entrez/query.fcgi?cmd=Retrieve $\& \mathrm{db}=$ PubMed\&lis t_uids=24678383\&dopt=Abstract)

43. Bjork J, Brown C, Friedlander H, Schiffman E, Neitzel D. Validation of random sampling as an estimation procedure for Lyme disease surveillance in Massachusetts and Minnesota. Zoonoses Public Health 2018 Mar;65(2):266-74. http://dx.doi.org/10.1111/zph.12297. PubMed (https://www. ncbi.nlm.nih.gov/entrez/query.fcgi?cmd=Retrieve\&db=PubM ed\&list_uids=27488080\&dopt=Abstract)

44. Lukacik G, White J, Noonan-Toly C, DiDonato C, Backenson PB. Lyme disease surveillance using sampling estimation: evaluation of an alternative methodology in New York State. Zoonoses Public Health 2018 Mar;65(2):260-5. http://dx.doi. org/10.1111/zph.12261. PubMed (https://www.ncbi.nlm. nih.gov/entrez/query.fcgi?cmd=Retrieve $\& d b=$ PubMed\&li st_uids=26924579\&dopt=Abstract)

45. Millen K, Kugeler KJ, Hinckley AF, Lawaczeck EW, Mead PS. Elevated Lyme disease seroprevalence among dogs in a nonendemic county: harbinger or artifact? Vector
Borne Zoonotic Dis 2013 May;13(5):340-1. http://dx.doi. org/10.1089/vbz.2012.1025. PubMed (https://www.ncbi.nlm. nih.gov/entrez/query.fcgi?cmd=Retrieve\&db=PubMed\&li st_uids $=27488080 \&$ dopt $=$ Abstract)

46. Ogden NH, Koffi JK, Lindsay LR. Évaluation d'un test de dépistage devant servir à déterminer le risque de la maladie de Lym. Relevé des maladies transmissibles au Canada 2014 Mar;40(5):87-92. https://www.canada.ca/fr/santepublique/services/rapports-publications/releve-maladiestransmissibles-canada-rmtc/numero-mensuel/2014-40/rmtcvolume-40-5-6-mars-2014/rmtc-volume-40-5-6-mars-2014-1. html

47. Waddell LA, Greig J, Mascarenhas M, Harding S, Lindsay R, Ogden N. The accuracy of diagnostic tests for Lyme disease in humans, a systematic review and meta-analysis of North American research. PLoS One 2016 Dec;11(12):e0168613. http://dx.doi.org/10.1371/journal.pone.0168613. PubMed (https://www.ncbi.nlm.nih.gov/entrez/query.fcgi?cmd=Retrie ve\&db=PubMed\&list_uids=28002488\&dopt=Abstract)

48. Daltroy LH, Phillips C, Lew R, Wright E, Shadick NA, Liang $\mathrm{MH}$. A controlled trial of a novel primary prevention program for Lyme disease and other tick-borne illnesses. Health Educ Behav 2007 Jun;34(3):531-42. http://dx.doi. org/10.1177/1090198106294646. PubMed (https://www. ncbi.nlm.nih.gov/entrez/query.fcgi?cmd=Retrieve\&db=PubM ed\&list_uids=17468463\&dopt=Abstract)

49. Ajzen I. The theory of planned behavior. Organ Behav Hum Decis Process 1991;50:179-211. http://dx.doi. org/10.1016/0749-5978(91)90020-T

50. Ajzen I, Fishbein M. Understanding attitudes and predicting social behavior. Englewood Cliffs, NJ: Prentice Hall; 1980.

51. Bandura A. Social foundations of thought and action. Englewood Cliffs, NJ: Prentice Hall; 1986.

52. Becker $\mathrm{MH}$. The health belief model and preventative health behavior. Health Educ Monogr 1974;2(4):354-86. http://journals.sagepub.com/doi/abs/10.1177/1090 19817400200405?journalCode=heba. http://dx.doi. org/10.1177/109019817400200407

53. Janz NK, Becker MH. The Health Belief Model: a decade later. Health Educ Q 1984;11(1):1-47. http://dx.doi. org/10.1177/109019818401100101. Pubmed (https://www. ncbi.nlm.nih.gov/entrez/query.fcgi?cmd=Retrieve\&db=PubM ed\&list_uids=6392204\&dopt=Abstract)

54. Ogden NH, Koffi JK, Pelcat Y, Lindsay LR. Environmental risk from Lyme disease in central and eastern Canada: a summary of recent surveillance information. Can Commun Dis Rep 2014 Mar;40(5):74-82. www.canada.ca/en/public-health/ services/reports-publications/canada-communicabl e-disease-report-ccdr/monthly-issue/2014-40/ccdr-volume40-5-march-6-2014/ccdr-volume-40-5-march-6-2014.html

55. Public Health Agency of Canada. Lyme disease. Ottawa (ON): PHAC; 2015. https://www.canada.ca/en/public-health/ services/diseases/lyme-disease.htmldiseases-condition s-maladies-affections/disease-maladie/lyme/index-eng.php 
62. Hitt E. Poor sales trigger vaccine withdrawal. Nat Med 2002 Apr;8(4):311-2. http://dx.doi.org/10.1038/ nm0402-311b. PubMed (https://www.ncbi.nlm.nih.gov/ entrez/query.fcgi?cmd=Retrieve\&db=PubMed\&list_ uids=11927918\&dopt=Abstract)

63. Poland GA. Vaccines against Lyme disease: what happened and what lessons can we learn? Clin Infect Dis 2011 Feb;52 Suppl 3:s253-8. http://dx.doi.org/10.1093/ cid/ciq116. PubMed (https://www.ncbi.nlm.nih.gov/ entrez/query.fcgi?cmd=Retrieve \&db=PubMed\&list_ uids=21217172\&dopt=Abstract)

64. Nepereny J, Vrzal V, Raska M, Weigl E, Krupka M, Turanek J, Masek J. Antibody response of dogs after immunisation with chimeric vaccine against borreliosis. Procedia Vaccinol 2015;9:31-4. http://dx.doi.org/10.1016/j.provac.2015.05.005

65. Töpfer KH, Straubinger RK. Characterization of the humoral immune response in dogs after vaccination against the Lyme borreliosis agent A study with five commercial vaccines using two different vaccination schedules. Vaccine 2007 Jan;25(2):314-26. http://dx.doi.org/10.1016/j. vaccine.2006.07.031. PubMed (https://www.ncbi.nlm.nih. gov/entrez/query.fcgi?cmd=Retrieve \&db=PubMed\&lis t_uids=16930782\&dopt=Abstract)

66. Centers for Disease Control and Prevention. Cost of Lyme disease (COLD) Study. Atlanta (GA): CDC; 2014. www.cdc. gov/ticknet/cold.html

67. Sivaramalingam B, Young I, Pham MT, Waddell L, Greig J, Mascarenhas M, Papadopoulos A. Scoping review of research on the effectiveness of food-safety education interventions directed at consumers. Foodborne Pathog Dis 2015 Jul;12(7):561-70. http://dx.doi.org/10.1089/ fpd.2014.1927. PubMed (https://www.ncbi.nlm.nih. gov/entrez/query.fcgi?cmd=Retrieve \&db=PubMed\&lis t_uids $=26135891 \&$ dopt $=$ Abstract)

68. Gould LH, Nelson RS, Griffith KS, Hayes EB, Piesman J, Mead PS, Cartter ML. Knowledge, attitudes, and behaviors regarding Lyme disease prevention among Connecticut residents, 1999-2004. Vector Borne Zoonotic Dis 2008 Dec;8(6):769-76. http://dx.doi.org/10.1089/ vbz.2007.0221. PubMed (https://www.ncbi.nlm.nih. gov/entrez/query.fcgi?cmd=Retrieve $\& \mathrm{db}=$ PubMed\&lis t_uids=18637724\&dopt=Abstract) 


\section{Appendices}

\section{Appendix 1: General characteristics of 2,258 included articles}

\begin{tabular}{|c|c|c|}
\hline Characteristic & $\mathbf{n}$ & $\%$ of total \\
\hline \multicolumn{3}{|l|}{ Publication date } \\
\hline before 1990 & 194 & 8.6 \\
\hline 1990-1994 & 406 & 18.0 \\
\hline 1995-1999 & 398 & 17.6 \\
\hline 2000-2004 & 334 & 14.8 \\
\hline 2005-2009 & 342 & 15.2 \\
\hline$>2010$ & 584 & 25.8 \\
\hline \multicolumn{3}{|l|}{ Document type } \\
\hline Journal article & 1,869 & 82.8 \\
\hline Conference proceeding/abstract & 183 & 8.1 \\
\hline Government or research report & 79 & 3.5 \\
\hline Thesis & 21 & 0.9 \\
\hline Book chapter & 16 & 0.7 \\
\hline Other ${ }^{\mathrm{a}}$ & 90 & 4.0 \\
\hline \multicolumn{3}{|l|}{ Study location ${ }^{b}$} \\
\hline $\begin{array}{l}\text { North America (Canada, United } \\
\text { States, Mexico) }\end{array}$ & $1,597^{c}$ & 70.8 \\
\hline Europe & 615 & 27.2 \\
\hline Asia & 57 & 2.5 \\
\hline Central/South America & 7 & 0.3 \\
\hline Australasia & 6 & 0.3 \\
\hline Africa & 3 & 0.1 \\
\hline \multicolumn{3}{|l|}{ Study design } \\
\hline Evaluation of diagnostic test ${ }^{d}$ & 736 & 32.6 \\
\hline \multicolumn{3}{|l|}{ Observational study } \\
\hline Cross-sectional & 664 & 29.4 \\
\hline Prevalence surveys & 371 & 16.4 \\
\hline Case study or case-series & 49 & 2.2 \\
\hline Cohort & 47 & 2.1 \\
\hline Case-control & 34 & 1.5 \\
\hline \multicolumn{3}{|l|}{ Experimental study } \\
\hline Controlled trial & 93 & 4.1 \\
\hline Challenge trial & 68 & 3.0 \\
\hline Quasi experiment & 13 & 0.6 \\
\hline Surveillance program & 181 & 8.1 \\
\hline Risk assessment & 11 & 0.5 \\
\hline Qualitative study & 13 & 0.6 \\
\hline Economic model & 8 & 0.4 \\
\hline Disease transmission model & 3 & 0.1 \\
\hline Other ${ }^{\mathrm{e}}$ & 26 & 1.2 \\
\hline
\end{tabular}

Appendix 1: (continued) General characteristics of 2,258 included articles

\begin{tabular}{|c|c|c|}
\hline Characteristic & $\mathbf{n}$ & $\%$ of total \\
\hline \multicolumn{3}{|l|}{ Format used to report study results } \\
\hline Prevalence & 1,278 & 56.6 \\
\hline Dichotomous outcome & 556 & 24.6 \\
\hline Continuous outcome & 358 & 15.8 \\
\hline $\begin{array}{l}\text { Measure of association (e.g., odds } \\
\text { ratio, relative risk) }\end{array}$ & 202 & 8.9 \\
\hline $\begin{array}{l}\text { Spatial analysis (includes satellite/ } \\
\text { remote sensing) }\end{array}$ & 43 & 1.9 \\
\hline Ordinal/Likert scale scores & 33 & 1.5 \\
\hline \multicolumn{3}{|l|}{ Model outcomes } \\
\hline$P$-values & 265 & 11.7 \\
\hline Sensitivity and specificity & 121 & 5.4 \\
\hline Coefficients/beta parameters & 97 & 4.3 \\
\hline Confidence limits & 96 & 4.2 \\
\hline $\mathrm{R}^{2}$ & 83 & 3.7 \\
\hline Standard error/standard deviation & 77 & 3.4 \\
\hline Sensitivity only & 13 & 0.6 \\
\hline Specificity only & 7 & 0.3 \\
\hline Other ${ }^{f}$ & 11 & 0.5 \\
\hline Non-extractable format & 798 & 35.3 \\
\hline $\begin{array}{l}\text { Author identified need for more } \\
\text { studies (yes vs no) }\end{array}$ & 806 & 35.7 \\
\hline \multicolumn{3}{|c|}{$\begin{array}{l}\text { Abbreviations: } n \text {, number; } \mathrm{R}^{2} \text {, the coefficient of determination and is the proportion of the } \\
\text { variance in the dependent variable that is predictable from the independent variable(s) } \\
\text { a Other document types include: letters to the journal editor or correspondence, brief } \\
\text { communications, newsletters/bulletins, guidelines/police statements, poster, patent, PowerPoint } \\
\text { presentation } \\
\text { b Multiple answers allowed per article in some categories (i.e., percentages do not add to } 100 \% \text { ) } \\
\text { c Only relevant research from North America on surveillance, and public and health professionals/ } \\
\text { physicians knowledge, attitudes and/or risk perceptions towards LD and potential prevention } \\
\text { and control strategies was characterised, consequently there was considerably more research } \\
\text { characterised from North America } \\
\text { d Enzyme-linked immunosorbent assay (ELISA), enzyme immunoassay (EIA) or } \\
\text { immunofluorescence assay (IFA), Western blot, polymerase chain reaction (PCR) tests, culture and } \\
\text { microscopy were most frequently reported } \\
\text { e Includes spatial analysis, predictive models, cost effectiveness, risk models and longitudinal } \\
\text { correlation } \\
\text { f Includes simulation model, percentage of total surveyed, presence or absence, behaviour results, } \\
\text { percent reduction, percentage of control, genomic information and tick bite reduction ratio }\end{array}$} \\
\hline
\end{tabular}


Appendix 2: Summary of primary research articles on B. burgdorferi s.l, host species and vectors $(N=2,258)$

\begin{tabular}{|c|c|c|}
\hline Pathogen, host and vector & $\begin{array}{c}\text { Number of } \\
\text { studies }^{\mathrm{a}}\end{array}$ & $\%^{a}$ \\
\hline \multicolumn{3}{|c|}{ Borrelia burgdorferi s.l. species $(n=1,808)$} \\
\hline burgdorferi s.s. & 1,664 & 73.7 \\
\hline garinii & 219 & 9.7 \\
\hline afzelii & 220 & 9.7 \\
\hline burgdorferi s.l. ${ }^{b}$ & 118 & 5.3 \\
\hline valaisiana & 57 & 2.5 \\
\hline miyamotoi & 53 & 2.3 \\
\hline lonestari & 44 & 1.9 \\
\hline bissetti & 31 & 1.4 \\
\hline spielmanii & 25 & 1.1 \\
\hline lusitaniae & 22 & 1.0 \\
\hline Borrelia spp. & 18 & 0.8 \\
\hline andsersonii & 12 & 0.5 \\
\hline anserina & 10 & 0.4 \\
\hline Other ${ }^{c}$ & 128 & 5.7 \\
\hline \multicolumn{3}{|l|}{ Host species ( $n=1,841)$} \\
\hline Humans & 1,154 & 51.2 \\
\hline \multicolumn{3}{|l|}{ Rodents } \\
\hline Mouse & 261 & 11.5 \\
\hline Voles & 78 & 3.5 \\
\hline Rat & 59 & 2.6 \\
\hline Chipmunk & 51 & 2.3 \\
\hline Squirrel & 50 & 2.2 \\
\hline Other $^{d}$ & 9 & 0.4 \\
\hline Dogs (companion) & 228 & 10.1 \\
\hline Deer & 138 & 6.1 \\
\hline Birds & 76 & 3.4 \\
\hline Horses & 60 & 2.7 \\
\hline Shrew & 44 & 1.9 \\
\hline Farm animals ${ }^{\mathrm{e}}$ & 35 & 1.5 \\
\hline Raccoons & 32 & 1.4 \\
\hline Rabbits & 28 & 1.2 \\
\hline Cats (companion) & 26 & 1.2 \\
\hline Lizards & 22 & 1.0 \\
\hline Opossums & 17 & 0.8 \\
\hline Other ${ }^{f}$ & 75 & 3.3 \\
\hline \multicolumn{3}{|l|}{ Vectors ( $n=789$ ) } \\
\hline Ixodes scapularis & 459 & 20.3 \\
\hline Ixodes ricinus & 149 & 6.6 \\
\hline Dermacentor variabilis & 112 & 5.0 \\
\hline Ixodes ipacificus & 104 & 4.6 \\
\hline
\end{tabular}

Appendix 2: (continued) Summary of primary research articles on $B$. burgdorferi s.l, host species and vectors $(\mathrm{N}=2,258)$

\begin{tabular}{|l|r|r|}
\hline Pathogen, host and vector & $\begin{array}{c}\text { Number of } \\
\text { studies }\end{array}$ & \multicolumn{2}{|c|}{$\%^{\mathrm{a}}$} \\
\hline Vectors (n=789) & 92 & 4.1 \\
\hline Amblyomma americanum & 46 & 2.0 \\
\hline Haemaphysalis leporispalustris & 32 & 1.4 \\
\hline Ixodes dentatus & 27 & 1.2 \\
\hline Amblyomma maculatum & 26 & 1.2 \\
\hline Dermacentor occidentalis & 27 & 1.2 \\
\hline Dermacentor albipictus & 24 & 1.1 \\
\hline Ixodes spinipalpis & 24 & 1.1 \\
\hline Ixodes cookei & 18 & 0.8 \\
\hline Rhipicephalus sanguineus & 20 & 0.9 \\
\hline Ixodes muris & 18 & 0.8 \\
\hline Ixodes angustus & 16 & 0.7 \\
\hline Ixodes persulcatus & 12 & 0.5 \\
\hline Ixodes texanus & 13 & 0.6 \\
\hline Ixodes affinis & 207 & 9.2 \\
\hline Otherg & & \\
\hline & 27 & \\
\hline
\end{tabular}

Abbreviations: $\mathrm{n}$, number; s.l., sensu lato; spp., species

a Multiple answers allowed per article in some categories (i.e. percentages do not add to $100 \%$ ) ${ }^{\mathrm{b}}$ Article reported B. burgdorferi s.I.

' Other Borrelia species: B. americana, B. bavariensis, B. coraceae, B. hermsii, B. japonica, B. parkeri, B. recurrentis, and B. turicatae. The species in bold are not associated with LD but were captured in our search and included for completeness. In five studies only "presence of spirochetes" was reported. Twenty-two other species were investigated in only one study (details are not reported here)

${ }^{d}$ Including woodchucks and other rodents types (investigated in only one study)

e Including cattle, sheep and goats

${ }^{f}$ Including bears, feral pigs and cats, fox, coyotes, Mustelidae family (weasels, otters and minks), Rhesus monkeys, skunks, moose, elk, wild sheep, bats, wolves, moles and other animals (investigated in only one study)

g Other "possible" vectors investigated in primary studies included the following: Amblyomma species: A. cajennense, A. inornatum, A. longirostre (Koch); Dermacentor species: D. andersoni, $D$. marginatus, D. nigrolineatus, D. parumapertus, D. reticulatus; Ixodes species: I. auritulus, I. baergi, I. brunneus, I. hearlei, I. hexagonus, I. jellison, I. kingi, I. marxi, I. minor, I. neotomae, I. sculptus, I. trianguliceps, I. woodi, I. uriae; Haemaphysalis species: H. concinna, H. qinghaiensis, $H$. punctate; Rhipicephalus species: R. annulatus, R. bursa, R. turanicus and R. (Boophilus) microplus 